\title{
EVIDENCE THAT THE PROTEIN COMPONENTS OF BOVINE ERYTHROCYTE GREEN HEME BINDING PROTEIN AND FLAVIN REDUCTASE ARE IDENTICAL
}

\author{
Department of Biological Chemistry \\ Medical School \\ The University of Michigan \\ Ann Arbor, Michigan 48109-0606
}

Kim S. Quandt, Feng Xu, Ping Chen, and Donald E. Hultquist*

Received June 3, 1991

SUMMARY: Bovine erythrocyte green heme binding protein and bovine erythrocyte flavin reductase have been isolated in highly purified forms and subjected to amino acid analysis and $\mathrm{N}$ terminal amino acid sequence analysis. The two proteins possess similar amino acid compositions and identical N-terminal amino acid sequences. Moreover, the two proteins are immunochemically cross-reactive and are indistinguishable when compared by sodium dodecyl sulfate-polyacrylamide gel electrophoresis and by double diffusion technique. This study provides evidence that the protein components of bovine erythrocyte green heme binding protein and flavin reductase are identical. 1991 academic Press, Inc.

Green heme binding protein, GHBP, is a water-soluble protein which has been isolated from hemolysates of bovine and human erythrocytes (1-3). The unique spectral properties of the hemeprotein arise from its highly conjugated, polar, and unstable prosthetic group, which is distinguishable from all known hemes $(4,5)$. This hemeprotein is remarkable in that its ferrous form undergoes extremely rapid autoxidation, and both its ferrous and ferric forms readily react with peroxides to yield completely colorless products (6).

Flavin reductase, FR, is a protein which has been isolated from hemolysates of human and animal erythrocytes (7-11). This protein has variously been referred to as an erythrocyte $N A D P H$ dehydrogenase, diaphorase, and methemoglobin reductase. The reductase activity ascribed to this protein was first reported 60 years ago as a methemoglobin reductase activity of erythrocytes in the presence of methylene blue (12-14). Subsequently, stimulations of methemoglobin reduction by dyes and by flavin have been observed in hemolysates and reconstituted systems (15). Evidence suggests that the reductase catalyzes the transfer of electrons from NADPH to the dye or flavin, and that the resulting reduced form of the dye or flavin then chemically reduces methemoglobin $(12,16,17)$. This stimulation constitutes the basis for the therapeutic use of methylene blue $(13,14,18)$ and flavin $(19,20)$ in the treatment of congenital and toxic methemoglobinemia.

* To whom correspondence should be addressed.

ABBREVIATIONS USED: GHBP, green heme binding protein; FR, flavin reductase; SDS-PAGE, sodium dodecyl sulfate-polyacrylamide gel electrophoresis; MCD, magnetic circular dichroism; Lys-C, lysyl endopeptidase. 
However, under normal in vivo conditions, the reductase plays a very minor role in reducing methemoglobin (21).

In this paper we report the $\mathrm{N}$-terminal amino acid sequences and the amino acid compositions of bovine erythrocyte green heme binding protein and flavin reductase. These analyses, together with electrophoretic and immunochemical studies, provide evidence that the protein components of these two proteins are identical. Some of these data have been presented previously in abstract form $(22,23)$.

\section{MATERIALS AND METHODS}

Materials. Freund's complete and incomplete adjuvants were obtained from DIFCO Laboratories. Electrophoresis-purity reagents and silver stain low range molecular weight protein standards (phosphorylase b, bovine serum albumin, ovalbumin, carbonic anhydrase, soybean trypsin inhibitor and lysozyme) were obtained from Bio-Rad. For immunoblotting, prestained low molecular weight protein standards (ovalbumin, carbonic anhydrase, $\beta$-lactoglobulin, lysozyme, bovine trypsin inhibitor, A and B chains of insulin) were obtained from Bethesda Research Laboratories. Nitrocellulose was obtained from Schleicher \& Schuell and nitro blue tetrazolium, 5-bromo-4-chloro-3-indoyl phosphate, and alkaline phosphatase-conjugated anti-rabbit IgG (developed in goat) from Sigma. Lysyl endopeptidase (Lys-C) of achromobacter lyticus M497-1 was obtained from Wako Chemicals USA.

General methods. Spectrophotometry was performed on a Kontron Uvikon 80. Protein was quantitated by the Pierce BCA method using bovine serum albumin as standard (24).

Extinction coefficients were determined for pure FR at $268 \mathrm{~nm}$, and for pure GHBP at $416 \mathrm{~nm}$, using protein contents obtained from the BCA method. Thereafter, FR and GHBP concentrations were calculated using absorbance at $268 \mathrm{~nm}$ or $416 \mathrm{~nm}$. SDS-PAGE was performed with a BioRad Mini-Protean II Dual Slab Cell using a discontinuous buffer system (25) and gels were stained with silver (26). For immunoblotting, proteins were electro-transferred from gel to nitrocellulose (27) using a Bio-Rad Trans-Blot Cell. Immunoblotting was performed using antiserum to bovine erythrocyte GHBP and alkaline phosphatase-conjugated anti-rabbit IgG, and color was developed using 5-bromo-4-chloro-3-indoyl phosphate and nitro blue tetrazolium. Two-dimensional double diffusion was allowed to proceed for 12 to $24 \mathrm{~h}$ in gels containing $1 \%$ purified agar and $0.85 \%$ $\mathrm{NaCl}$ buffered with $0.1 \mathrm{M}$ phosphate, $\mathrm{pH} 7.2(28)$.

Purification of GHBP and FR. Bovine erythrocyte GHBP (form I) was purified according to the previously published procedure (3).

Bovine erythrocyte FR was purified by a modification of the chromatographic procedures used by Yubisui et al. to purify flavin reductase from human erythrocytes (11). The FR which had been purified by chromatography on DEAE-cellulose and Bio-Gel P-60 and then re-chromatographed on Bio-Gel P-60 was found by SDS-PAGE to be of high purity and was used without further purification.

Antisera production. Antisera to bovine erythrocyte GHBP were raised by immunization of young adult male New Zealand White rabbits. Each animal was given eight to twelve intradermal injections on the back, for a total of $50 \mu \mathrm{g}$ of purified GHBP in $1 \mathrm{ml}$ of emulsified Freund's complete adjuvant. During the second week, booster injections totaling $50 \mu \mathrm{g}$ of GHBP in Freund's complete adjuvant were again given intradermally. During the fourth week, booster injections totaling $50 \mu \mathrm{g}$ of GHBP in Freund's incomplete adjuvant were given intramuscularly and subcutaneously. A week after the last booster injection, and every two weeks thereafter, blood was collected from ear veins, allowed to clot, centrifuged at $9000 \times g$ for $10 \mathrm{~min}$, and the sera decanted. Specificity of the antisera was tested by immumoblotting. Antisera were stored at $-20^{\circ} \mathrm{C}$.

Amino acid analysis. The protein sample underwent gas phase hydrolysis in $6 \mathrm{~N} \mathrm{HCl}$ at $110^{\circ} \mathrm{C}$ for $24 \mathrm{~h}$. Amino acid analyses were performed by Fulvio Perini, Eric Malek, and Philip Andrews of the Protein Structure Facility of the University of Michigan using an Applied Biosystems Instrument 420H Amino Acid Analyzer and standard operating conditions. Tryptophan content of FR was quantitated by a magnetic circular dichroism (MCD) method (29) using a Jasco $\mathrm{J}-40 \mathrm{C}$ spectropolarimeter equipped with an electromagnetic capable of generating a $15 \mathrm{kG}$ magnetic field and interfaced with a Nova III computer and a Tracor $1500 \mathrm{~N}$ signal analyzer.

Preparation and separation of peptides derived from GHBP with Lys-C. Urea-denatured GHBP $(12.2 \mu \mathrm{g})$ was digested by Lys-C $(0.1 \mu \mathrm{g})$ for four $\mathrm{h}$ at $37^{\circ} \mathrm{C}$. Another aliquot of Lys-C 
was then added and the incubation continued for an additional four $h$. The resulting peptides were separated by reverse-phase HPLC, using an Aquapore RP-300 column and an aqueous trifluoroacetic acid/acetonitrile gradient in a Applied Biosystems Instrument 130A Separation System. Peptide peak fractions were collected manually into microtubes. Selected peptides were subjected to amino acid sequencing.

Amino acid sequencing. Amino acid sequencing was performed on an Applied Biosystem 470A Protein Sequencer interfaced with an Applied Biosystem 120A Analyzer and on an Applied Biosystems 473A Protein Sequencer. Prior to $\mathrm{N}$-terminal amino acid sequencing, GHBP was chemically reduced and any Cys residues were alkylated with vinylpyridine. The sequencing was performed by Kim Mountjoy, Sari Vlahakis, and Philip Andrews of the Protein Structure Facility of the University of Michigan.

\section{RESULTS}

Bovine erythrocyte green heme binding protein and flavin reductase migrate identically on SDS-PAGE, as shown by the silver-stained gel in Fig. 1A. The two proteins are immunochemically cross-reactive, as shown in the immunoblot in Fig. 1B, which utilized rabbit antiserum elicited against purified bovine erythrocyte GHBP.

The two proteins form lines of identity upon agar-gel double diffusion using the antiGHBP serum, as shown in Fig. 2. The polyclonal antibodies precipitate only one band in bovine hemolysate and do not react with bovine hemoglobin.

The results of the amino acid analyses of bovine erythrocyte GIIBP and FR are reported in Table I, expressed as the number of residues for a protein of 23,000 daltons. Tryptophan content of FR was determined by MCD to be 1.4 mole Trp/mole of protein.

The results of N-terminal amino acid sequencing of bovine erythrocyte GHBP and FR are presented in Table II. The sequencing of GHBP was interpretable for 36 cycles, with three

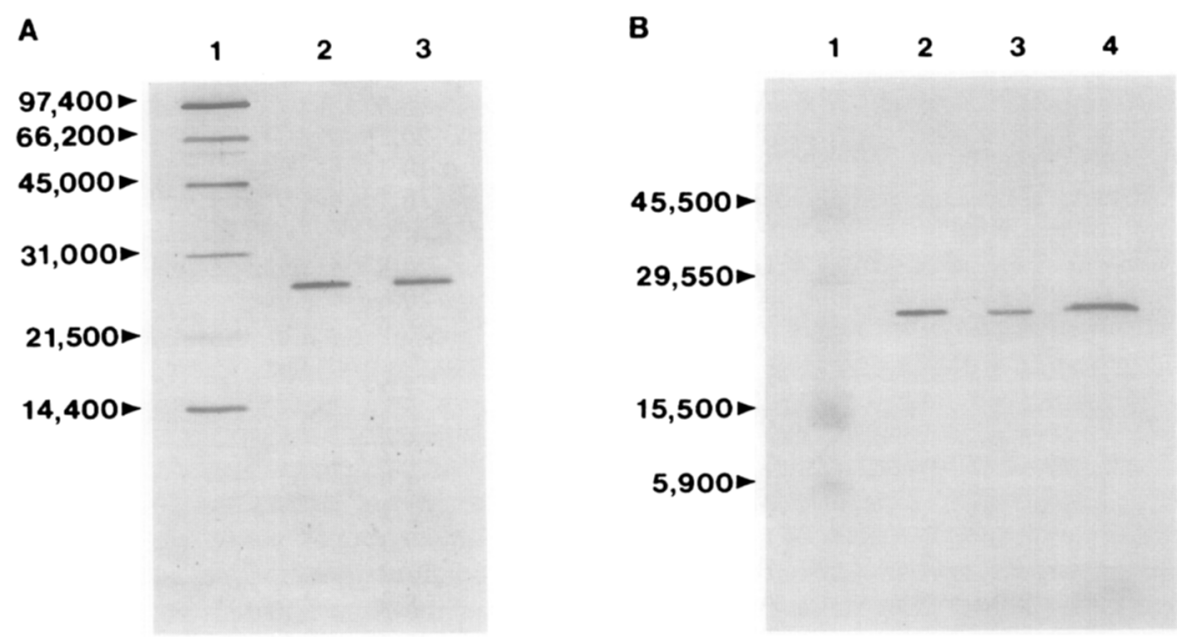

FIG. 1. Comparison of GHBP and FR. A. SDS-PAGE. Proteins were electrophorectically separated on a $15 \%$ SDS-polyacrylamide gel and then silver stained. Lane 1, protein molecular weight standards, sizes as indicated; lane 2, purified bovine erythrocyte GHBP (50 ng); lane 3, purified bovine erythrocyte FR ( $50 \mathrm{ng}$ ). B. Immunoblot. Proteins were electrophoretically separated on a $15 \%$ SDS-polyacrylamide gel, electrotransferred to nitrocellulose, and then blotted using antiserum against bovine erythrocyte GHBP. Lane 1, prestained protein molecular weight standards, sizes as indicated; lane 2, purified bovine erythrocyte GHBP ( $20 \mathrm{ng}$ ); lane 3, purified bovine erythrocyte FR ( $20 \mathrm{ng})$; lane 4 , bovine hemolysate $(20 \mu \mathrm{g}$ total protein). 


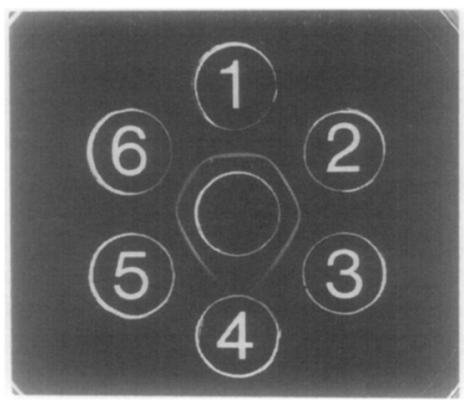

FIG. 2. Comparison of GHBP and FR by agar-gel double diffusion. The central well contained ammonium sulfate-precipitated antiserum from rabbit which had been injected with purified bovine erythrocyte GHBP. Wells land 3, purified bovine erythrocyte FR (4 $\mu \mathrm{g})$; wells 2 and 5, purified bovine erythrocyte GHBP $(4 \mu \mathrm{g})$; well 4 , bovine hemoglobin $(4 \mu \mathrm{g})$; well 6 , bovine hemolysate (1.5 mg total protein).

positions of uncertainties. The sequencing of FR was interpretable for 36 cycles with one position of uncertainty.

The results of amino acid sequencing of peptides derived from GHBP by Lys-C digestion are presented in Table III. Of the 24 peaks resolved on HPLC, three peptides were subjected to amino acid sequencing: \#7, which eluted from the HPLC at $49.2 \mathrm{~min}$; \#11, which eluted at 58.0

Table I

Amino Acid Analysis of Bovine Erythrocyte GHBP and FR

\begin{tabular}{ccc}
\hline Amino Acid & GHBP $^{\mathrm{a}}$ & FR $^{\mathrm{b}}$ \\
\hline Asx & 21.5 & 15.9 \\
Thr & 18.3 & 20.1 \\
Ser & 11.8 & 10.1 \\
Glx & 15.7 & 16.1 \\
Pro & 15.9 & $16.8^{\mathrm{c}}$ \\
Gly & 21.3 & 20.8 \\
Ala & 20.0 & 20.8 \\
Val & 24.5 & 26.9 \\
Cys &.- &.- \\
Met & 4.3 & 2.2 \\
Ile & 5.4 & 6.3 \\
Leu & 19.1 & 22.2 \\
Tyr & 5.8 & 4.9 \\
Phe & 3.9 & 2.7 \\
Lys & 8.8 & 9.3 \\
His & 10.3 & 12.2 \\
Arg & 8.4 & 8.7 \\
Trpd &.- & 1.4 \\
\end{tabular}

\footnotetext{
average of three analyses.

${ }^{b}$ Avcrage of two analyses.

c Pro content in FR was determined in a single analysis.

d Trp content of FR was determined by the MCD method. Trp content of GHBP was not determined by this method since it can not be applied to hemeproteins.
} 
Table II

Amino-Terminal Sequences of Erythrocyte GHBP and FR

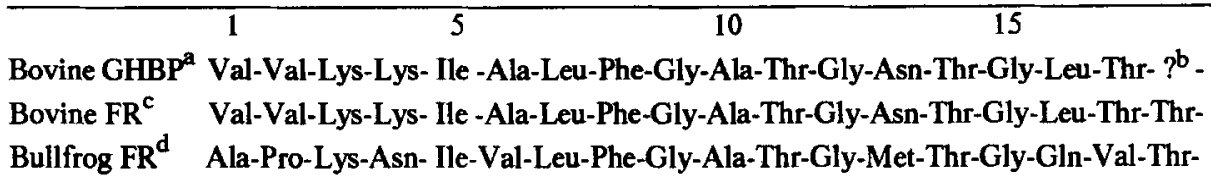

20

25

30

$35 \quad 36$

Bovine GHBP Leu-Ala -Gin-Ala-Val-Gln-Ala-Gly-Tyr-Glu-Val- ?b -Val- ?b- Val-Arg-Asp-Pro - Bovine FR Leu-Ala-Gln-Ala-Val-Gln-Ala-Gly-Tyr-Glu-Val-Thr-Val-Leu- ?b-Arg-Asp-Pro - . Bullfrog FR Leu-Gly -Gln-Ala-Leu-Glu - .

${ }^{a}$ GHBP was chemically reduced and any Cys alkylated with vinylpyridine prior to sequencing. Repetitive yields of sequencing were $86 \%$ to $94 \%$.

${ }^{b}$ Amino acid was not identified.

${ }^{c}$ Repetitive yields of sequencing were $93 \%$ to $97 \%$.

${ }^{\mathrm{d}}$ From reference 31 .

min; and \#21, which eluted at 73.1 min. Peptide \#7 was sequenced for its full length of 17 residues, with one position of uncertainty. Peptides \#11 was sequenced for 24 cycles, with one position of uncertainty. Peptides \#21 was analyzed for five cycles before sequencing was terminated, when it became apparent that this peptide was derived from the $\mathrm{N}$-terminal region that had already been sequenced.

\section{DISCUSSION}

Green heme binding protein and flavin reductase possess identical $\mathbf{N}$-terminal amino acid sequences and they have very similar amino acid compositions. Moreover, these two bovine erythrocyte proteins are immunochemically cross-reactive and are indistinguishable by SDS-PAGE

\section{Table III}

Partial Sequences of Peptides Derived from a Lys-C Digest of Bovine Erythrocyte GHBP

Peptide \# $7^{\text {a }}$

Val-Pro- ?b -Arg-Leu-Gln-Asp-Val-Thr-Asp-Asp-His- Ile-Arg-Met-His-Lys

Peptide \#11 ${ }^{\mathrm{c}}$

Tyr-Val-Ala- Val-Met-Pro- ? ? $^{\mathrm{b}}$-His- Ile-Glu-Asp-His-Pro-Leu-Thr-Gly- Ala-Tyr-Thr-ValThr-Leu-Asp-Gly . -

Peptide \#21 ${ }^{\text {d }}$

Ile-Ala-Leu-Phe-Gly - -

${ }^{a}$ Eluted from the HPLC column at $49.2 \mathrm{~min}$. Repetitive yields of sequencing were $87 \%$ to $93 \%$.

${ }^{b}$ Amino acid was not identified.

${ }^{c}$ Eluted from the HPLC column at 58.0 min. Repetitive yields of sequencing were $86 \%$ to $92 \%$.

d Eluted from the HPLC column at $73.1 \mathrm{~min}$. 
and double diffusion. These results indicate that the protein components of bovine erythrocyte GHBP and bovine erythrocyte FR are identical. Final demonstration of identity must await the determination of the complete amino acid sequence of both proteins.

The $\mathrm{N}$-terminal sequence does not have an initial methionine residue, suggesting that post-translational processing of the protein has occurred. The $\mathrm{N}$-terminal region possesses three cationic charges, the amino-terminal Val, Lys-3 and Lys-4, whereas the adjacent stretch of 23 residues is completely hydrophobic. There is an interesting tandem repeating sequence, Gly-X-Thr, found between residues Gly-9 and Thr-17.

Inspection of the sequence of peptide \#21 derived from GHBP by Lys-C digestion reveals that this peptide is probably derived from the $\mathrm{N}$-terminal region as a result of cleavage on the carboxyl side of Lys-4 to yield a peptide starting with Ile-5. Peptides \#7 and \#11 are internal sequences. In contrast to the $\mathrm{N}$-terminal sequence, peptide \#7 is very hydrophilic, possessing six charged amino acids and three polar amino acids in this stretch of 17 residues.

This bovine erythrocyte protein shows similarity to the structural features which have reported for FR from human (30) and bullfrog (31) erythrocytes. Bullfrog FR has an analogous cationic $\mathrm{N}$-terminal region followed by a hydrophobic region, as shown in Table II. Comparison of the N-terminal sequences of bovine and bullfrog FR shows that, of the first 24 residues $58 \%$ are identical and $20 \%$ represent a conservative change. The amino acid composition of the 25 $\mathrm{N}$-terminal residues of human FR has been reported and shows a striking similarity to bovine FR. In the $\mathrm{N}$-terminal region, each protein has 12 hydrophobic residues (Ala, Val, Leu, and Ile), 3 polar residues (Asn and Gln), 4 Thr residues, 3 Gly residues, 2 Lys residues, and one Phe residue. Likewise, the amino acid compositions of intact FR from bovine, human, and bullfrog are very similar.

Other than the homology to flavin reductases of other species, no significant homology was detected upon searching the proteins in the data base of the National Biomedical Research Foundation. Among the proteins sequences which showed no homology were catalase, cytochrome $b_{5}$, cytochrome P-450, glutathione-S-transferase, glutathione peroxidase, hemoglobin, myleoperoxidase, myoglobin, tryptophan oxidase, and tryptophan peroxidase.

The apparent identity of the protein components of GHBP and FR is surprising in light of the fact that the spectral and catalytic properties of these proteins have been reported over many decades to be markedly different. Our findings again raise the questions as to the nature of the chromophore or cofactor which is associated with this protein in vivo and as to the biological significance of this protein. Future structural and catalytic studies will attempt to establish whether the physiological significance of the protein lies in its classical but very low-level reductase activity, in its rapid reactions with oxygen and peroxide, or, as suggested recently (23) in its ability to bind protohemin.

ACKNOWLEDGMENT : This study was supported by USPHS NIH Grant AG-07046.

\section{REFERENCES}

1. Morrison, M. (1961) Nature 189, 765-766.

2. Morrison, M., Reed, D. W., and Hultquist, D. E. (1970) Biochim. Biophys. Acta 214, 389-395. 
3. DeFilippi, L. J., and Hultquist, D. E. (1978) J. Biol. Chem. 253, 2946-2953.

4. Hultquist, D. E., Dean, R. T., and Reed, D. W. (1976) J. Biol. Chem. 251, 3927-3932.

5. DeFilippi, L. J., and Hultquist, D. E. (1978) J. Biol. Chem. 253, 2954-2962.

6. DeFilippi, L. J., Ballou, D. P., and Hultquist, D. E. (1979) J. Biol. Chem. 254, 6917 6923.

7. Kiese, M. (1944) Biochem. Z. 316, 264-294.

8. Huennekens, F.M., Caffrey, R. W., Basford, R. E., and Gabrio, B. W. (1957) J. Biol. Chem. 227, 261-272.

9. Shrago, E., and Falcone, A. B. (1963) Biochim. Biophys. Acta 67, 147-149.

10. Scott, E. M., Duncan, I. W., and Ekstrand, V. (1965) J. Biol. Chem. 240, 481-485.

11. Yubisui, T., Matsuki, T., Takeshita, M., and Yoneyama, Y. (1979) J. Biochem. (Tokyo) 85,719-728.

12. Warburg, O., and Reid, A. (1931) Biochem Z. 242, 149-158.

13. Steele, C. W., and Spink, W. W. (1933) N. Engl. J. Med. 208, 1152-1153.

14. Williams, J. R., and Challis, F. E. (1933) J. Lab. Clin. Med. 19, 166-171.

15. Kiese, M. (1974) Methemoglobinemia: A Comprehensive Treatise. CRC Press, Cleveland.

16. Beutler, E., and Baluda, M. C. (1963) Blood 22, 323-333.

17. Yubisui, T., Takeshita, M., and Yonemaya, Y. (1980) J. Biochem. (Tokyo) 87, 1715-1720.

18. Hartmann, A. F., Perley, A. M., and Bamett, H. L. (1938) J. Clin. Invest. 17, 699-710.

19. Kaplan, J. C., and Chirouze, M. (1978) Lancet, II, 1043-1044.

20. Hirano, M., Matsuki, T., Tanishima, K., Takeshita, M., Shimizu, S., Nagamura, Y., and Yoneyama, Y. (1981) Br. J. Haematol. 47, 353-359.

21. Sass, M. D., Caruso, C. J., and Farhangi, M. (1967) J. Lab. Clin. Med. 70, 760-767.

22. Hultquist, D. E., Xu, F., Quandt, K., and Chen, P. (1990) FASEB Joumal 4, 2279 Abs.

23. Hultquist, D. E., Xu, F., Quandt-Tummino, K., and Chen, P. (1991) FASEB Journal 5, 1543Abs.

24. Smith, P. K., Krohn, R. I., Hermanson, G. T., Mallia, A. K., Gartner, F. H., Provenzano, M. D., Fujimoto, E. K., Goeke, N. M., Olson, B. J., and Klenk, D. C. (1985) Anal. Biochem. 150, 76-85.

25. Laemmli, U.K. (1970) Nature 227, 680-685.

26. Wray, W., Boulikas, T., Wray, V. P., and Hancock, R. (1981) Anal. Biochem. 118 , 197-203.

27. Towbin, H., Staehelin, T., and Gordon, J. (1979) Proc. Natl. Acad. Sci. U.S.A. $76,4350-4354$.

28. Clausen, J. (1988) Immunochemical Techniques for the Identification and Estimation of Macromolecules. Elsevier, New York, 1988.

29. Holmquist, B. and Vallee, B.L. (1973) Biochemistry 12, 4409-4417.

30. Yubisui, T., Tamura, M., and Takeshita, M. (1987) Biochem. Int. 15, 1-8.

31. Abe, Y., Ito, T., and Okazaki, T. (1990) J. Biochem. (Tokyo) 108, 255-260. 